Bartın Üniversitesi

Eğitim Fakültesi Dergisi

Cilt 6, Sayı 2, s. 427-446, Haziran 2017

BARTIN - TÜRKIYE

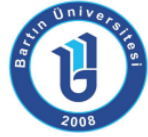

ISSN: 1308-7177
Bartin University

Journal of Faculty of Education

Volume 6, Issue 2, p. 427-446, June 2017

BARTIN - TURKEY

\title{
Sınıf Öğretmenlerinin Değer Öğretimine Yönelik Zihin Haritaları
}

Mevlüt GÜNDÜZ, Yrd. Doç. Dr. Süleyman Demirel Üniversitesi, Eğitim Fakültesi, mevlutgunduz@sdu.edu.tr

Vedat AKTEPE, Yrd. Doç. Dr. Nevşehir Hacı Bektaşi Veli Üniversitesi, Eğitim Fakültesi, vedataktepe@nevsehir.edu.tr

Öz: Bu çalışmanın amacı değer öğretiminde önemli bir yeri olan sınıf öğretmenlerinin zihin haritalarını incelemek ve değer algılarını ortaya çıkarmaktır. Araştırmada nitel araştırma desenlerinden biri olan fenomonolojik yaklaşım kullanılmıştır. Araştırma, 2016-2017 yılında Isparta il merkezinde görev yapan 15 sınıf öğretmeni ile yapılmıştır. Araştırmada veri toplama aracı olarak araştırmacı tarafından geliştirilen yarı yapılandırılmış görüşme formu kullanılmıştır. Araştırmada kullanılan veri toplama aracının güvenirliği Miles ve Huberman formülü ile tespit edilmiş ve \%95 oranında bir uzlaşma sağlanmıştır. Elde edilen veriler nitel araştırma tekniklerinde çok kullanılan betimsel analiz tekniğiyle çözümlenmiştir. Sonuç olarak bu araştırma göstermiştir ki araştırmaya katılan öğretmenler değer öğretimi adı altında verilmesi gereken çoğu değerin farkındadırlar. En çok ise dürüstlük değerini önemsemekle birlikte bu değerlere yönelik de farklı çağrışımlar oluşturmuşlardır.

Anahtar Kelimeler: zihin haritası, değer eğitimi, değer, öğretmen, sınıf öğretmenleri

\section{Intelligence Map of Class Teachers for Value Teaching}

\begin{abstract}
This study aims to examine intelligence map of class teachers and reveal their value perception. Phenomenological approach which is one of the qualitative research pattern is used in the research. The research covers 15 class teachers who work in Isparta city center. Semi-structured interview form is used in the paper which is developed by the researcher as data collection instrument. Reliability analysis of the research is determined by Miles and Huberman formula and a $95 \%$ compromise is provided. Collected data is analyzed via descriptive analysis methods which are constantly used in qualitative analysis methods. As a result of the study, it was found that teachers, who participated in the study, are aware of most ofthe values which are to teach students in the scope of values education. Although they pay more attention to honesty, they attached varied connotations to other values, too.
\end{abstract}

Key Words: intelligence map, value education, value, teacher, class teachers 


\section{GíRiş}

Zihin haritası, ilk kez Tony Buzan tarafından en kısa ve ilgi çekici not alma tekniği olarak geliştirilmiştir. Daha sonraları zihin haritası tekniği, not alma tekniği olmanın dışında çok farklı biçimlerde de kullanılmıştır. Zihin Haritası, beynin tüm potansiyelini açığa çıkarmak için evrensel anahtarlar sağlayan ve bilgiyi sınıflandıran güçlü bir grafik tekniğidir. Zihin haritaları beynin potansiyelini geliştirmede kullanılan, birçok alanda öğrenmeyi ve düşünmeyi kolaylaştırmakla birlikte ayrıca, düşüncelerimizi kesinleştirmemizi de sağladığını söylenebilir (De La Cruz-Bechtel, 2008:58; Buzan ve Buzan, 2010)

Bu çağda bilginin katlanarak çoğalması ve hızlı değişimi, eski 'bilgiye ulaşmaya yönelik eğitim sisteminde' de köklü değişimleri gerekli kılmıştır. Artık öğrencilere bilgiyi aktarmaktan çok, bilgilere nasıl ulaşacaklarını, nasıl değerlendireceklerini ve nasıl kullanacaklarını öğretmeye yönelik eğitim stratejileri önem kazanmıştır. İşte bu sebeple, zihin haritası tekniği de, bilgi aktarımından çok, bu bilginin kullanımını amaçlayan yeni bir teknik olarak da eğitim sisteminde yerini almıştır (Derelioğlu, 2005). Bunun yanında zihin haritalarının öğretmenlere, bilgilerin düzenlenmesinde ve öğrencilerin değerlendirilmesinde yardımcı olduğu görülmüştür (Hyerle, 1996).Zihin haritaları pekiştirme, vurgu yapma, özetleme, sınıflandırma, açıklama, tanımlama olanağı tanır. Ayrıca hatırlamayı da kolaylaştııı (Serrat, 2009; Evrekli, 2010).

Bir zihin haritasının oluşturulması ana konunun bir resim ya da imgeyle ifade edilmesiyle başlar, ana konuyla ilişkili dallar çizilir, her dalda konunun ya da sözcük öbeğinin temsil edildiği akılda kalıcı bir anahtar kelime yazılır ve daha sonra birbiriyle ilgili olan dallar ilişkilendirilir (Ladge, 2002; Şeyihoğlu ve Kartal, 2010).

Buzan ve Buzan (2010), zihin haritalarının oluşturulma sürecini kısaca şu şekilde özetliyor:

- Hedef konu, merkeze çizilen bir resim ile ifade edilir. Örneğin bir kitap planını haritalamayı düşünüyorsanız, kitabın resmini haritanızın merkezine koymalısınız.

- Merkezdeki resimden etrafa dallar yayılır. Öncelikle ana temalar dallandırılır, alt konular da bu dallardan yayılır.

- Her bir dalda, anahtar bir kelime veya resim kullanılır.

Zihin haritası, bir not alma tekniği olduğu kadar (Gür ve Bütüner, 2006), aynı zamanda bireyin düşündüklerini ve zihninde var olanları somutlaştırır (Evrekli ve Balım, 2010). Ayrıca bireyler haritalarını oluştururken şekil, imge ve anahtar sözcükleri kullandıkları için beynin sağ kısmının kullanımıyla haritadaki kavram ve düşünceler daha sonraki süreçlerde de hatırlanmasını kolaylaştırmaktadır. Bu nedenle zihin haritası, öğrenme hızının artması ve bilgilerin yeniden hatırlanması üzerinde güçlü bir etkiye sahiptir (Caine ve Caine, 2002 ; Zampetakis, Tsironis ve Moustakis, 2007; Balım vd., 2011).

Zihin haritalarının renkli, resimli olmaları ve öğrenenler tarafından kolaylıkla oluşturulmasından dolayı, onlara duyuşsal açıdan da tatmin sağlayacağı düşünülmektedir. Bu yönüyle bakıldığında, zihin haritalarını kullanmanın duyuşsal açıdan değerlendirilmesine ihtiyaç duyulmuştur. Öğrencinin davranışlarını şekillendiren duyuşsal özellikler, etkin ve kalıc bir öğrenmenin gerçekleşmesinde belirleyici bir rol üstlenebilir (Balaban-Salı, 2004: 176; Karataş, 2010). Zihin haritasıyla ilgili yapılan araştırmalarda yerli yabancı litaratüre baktığımızda; genellikle olumlu sonuçların tespit edildiği görülmüştür.

Liu (1995) çalışmasında zihin haritalama tekniğinin ilköğretim 5. sınıf öğrencilerinin dilsel yaratıcılık yetenekleri üzerindeki etkisini artırdığını, Farrand, Hussain ve Hennessy (2002), tıp fakültesinde okuyan öğrenciler üzerinde zihin haritalarının geri hatırlama üzerinde etkililiği artırdığını, Brinkmann (2003), zihin haritalarının başarıyı artırdığını, Ling 
(2004), zihin haritalarının öğrencilerin yazma becerileri üzerindeki etkisini artırdığını bulmuşlardır. Yine Derelioğlu (2005), çalışmasında hayat bilgisi ve sosyal bilgiler öğretimi dersinde akıl haritasının kullanımının öğrencilerin düşünme becerilerinin ve yaratıcılıklarının geliştirilmesi artırdığını, Fidan (2012), Fen ve Teknoloji dersinde bilgisayar destekli zihin haritası kullanımının öğrencilerin akademik başarısını artırdığını, tutumlarını geliştirdiğini ve kalıcılığı artırdığını bulmuştur.

Yapılan çalışmalara baktığımızda, zihin haritasının daha çok bilişsel alana yönelik katkıları olduğu yönünde araştırmalar yapılmıştır. Zihin haritalarını duyuşsal alana yönelik önemli katkıları olduğu gerçeği de göz önünde bulundurulmalıdır. Özellikle de değer eğitiminin öğrencilere daha etkili ve sağlıklı verilebilmesi noktasında zihin haritalarından yararlanabiliriz. Zihin haritası akla gelen çağrışımlar bütünü olduğu için bir öğrencinin bir değere yönelik çağrışımları ve düşünce yapısı, o değerin öğretilme şeklini etkileyeceği için bu noktada önem arz etmektedir.

Hiç kuşkusuz gelecek nesiller; büyüklerinden, ebeveynlerinden ve çevrelerindeki bilge insanlardan pek çok tecrübe edinirler. Fakat dünyaya dair bilgi ve gerçeğin kaynağının birçok farklı bilimsel yöntemler çerçevesinde yapılan nitel-nicel araştırmalar olduğu düşünüldüğünde, eğitim ve öğretimin bu durumda küçümsenmeyecek derecede etkili olduğu bilinmelidir (Doğanay, 2014:6). Bununla birlikte okullardaki eğitim, bireylerin zihinsel yeteneklerinin yanında duyuşsal yeteneklerini de geliştirmeye çalışmaktadır. Böylece eğitim, mesleki bilgi ve becerilerin yanında, insanların ahlaki ve estetik değerler kazanmalarını amaçlamaktadır. Özellikle ilkokul mertebesindeki öğrencilere birtakım bilgilerin, becerilerin, arzu edilen davranışların ve iyi değerlerin kazandırıması eğitimin temel amaçlarındandır (Arslan, 2012:388389).

Değer, bir sosyal grup veya toplumun kendi varlık, birlik, işleyiş ve devamını sağlamak ve sürdürmek için üyelerinin çoğunluğu tarafından doğru ve gerekli oldukları kabul edilen ortak düşünce, amaç, temel ahlâkî ilke ya da inançlar olarak tanımlanmaktadır (MEB, 2004; Dönmez ve Cömert, 2007). Adalet, demokrasi bilinci, dürüstlük, alçak gönüllülük, bağımsızlık, bağışlama, barış, Türk Bayrağına ve İstiklâl Marşı'na saygı, bilimsellik, cömertlik, çalışkanlık, doğa sevgisi, doğruluk, dostluk, emaneti korumak, fedakârlık, güvenirlik, hakseverlik, hayâ, hoşgörü, ibadet yerlerine saygı, iffet, kardeşlik, merhamet, millet sevgisi, misafirperverlik, namuslu olmak, sabır, saygı, sevgi, sorumluluk, sözünde durmak, şükür, tarihsel mirasa duyarlıık, temizlik, tutumluluk, vatanseverlik, vefa, yardımseverlik vb. değerler öğretim programında doğrudan verilecek değerler olarak yer almaktadır (MEB, 2004).

İçinde yaşadığımız toplumda kendisinden farklı düşündüğü ya da farklı inançlara sahip olduğu için, başkalarını hoşgörüyle karşılamayan, kendine ve sağlığına saygı duymadan kendisine zarar veren, sevgi, saygı, sorumluluk gibi değerleri kazanamayan insanlar bulunabilmektedir (Doğanay, 2007:270). Bu durum ancak doğru değer eğitimi yaklaşımları ve uygulamaları ile aşılabilecek birer toplumsal sorun olarak karşımıza çıkmaktadır.

Geçmişteki eğitim programlarında "ahlak eğitimi" ve " karakter eğitimi" şeklinde karşımıza çıkan değer kazandırma işleminin günümüzdeki yaygın ismi değerler eğitimidir (Keskin, 2012:83). Değerler eğitimi, değerler ve değerleri geliştirme süreci konusunda eğitim için açık bir girişimdir (Özen, Güleryüz ve Bulut-Özen, 2012). Akbaş’a (2015) göre değerler eğitimi kapsamında, toplumların binlerce yılda oluşturduğu temel değerler, duyuşsal alan eğitimine önem verilerek öğrencilere kazandırılmaya çalışımıştır.

Çocukların kişiliklerinin küçük yaşlarda oluşmaya başladığını düşünürsek bu değerlerin çocuklara kazandırılmaya çalışılması hem bireylerin kişisel mutluluğunu artıracak hem de kendini topluma faydalı bir birey olarak hissedecektir. Nitekim çocuklara sadece bilgi ağırlıklı 
öğretim verip duyuşsal alanlarını ihmal edersek bireyi bilişsel yönüyle iyi seviyelere çıkarabiliriz, ancak duygularla desteklenmeyen bilgi, insanı çok fazla mutlu etmeyecektir. Netice de bilgi, duygu ve davranışlar etkileşim içerisinde olduğu için bireyi birlikte etkileyecektir. Çünkü toplumsal değerleri benimsemiş, böylece sosyal ilişkilerinde sorunlar yaşamayan sağlıklı bireyler yetiştirmek değerler eğitimi ile mümkündür (Ateş, 2013:2).

Eğitim sisteminin temel taşı olan ilkokul kademesinde, bireylere toplum içinde diğer bireylerle uyum içinde yaşamaları ve yaşamlarını daha iyi bir biçimde sürdürmeleri için gerekli olan temel bilgi ve beceriler kazandırılmaktadır (Fidan ve Erden, 2001). Öğretmenlerin çocuklar üzerindeki etkisinin çok fazla olduğunu düşünürsek değer öğretiminde bu durum bir fırsat olarak değerlendirilmelidir. Çünkü bu dönemde çocuklar ebeveynlerden çok öğretmenlerinden etkilenirler. Öğrenciler, yaşamlarının en önemli dönemlerini okulda geçirdiği için, öğrencilere ömür boyu sürecek iyi bir değer eğitimi alışkanlığı kazandırma konusunda eğitim sistemimize ve özellikle uygulayıcı konumda olan öğretmenlere büyük görevler düşmektedir. Bu gibi nedenlerden dolayı ilkokul öğrencilerine öğretmenlerin ders esnasında kazandıracağı bilgi, beceri ve değerler önem arz etmektedir. Eğitilmeye ve öğretilmeye çok yatkın olunan bu dönemde, çocuklara öğretmenlerinin kazandıracağı değerler, çocukların ileride sahip olacakları kişiliklerinin temellerini atmada kritik bir rol üstlenmektedir. Ayrıca karşıdaki kitle çok küçükse ve biz onlara bir şeyler öğretmeyi amaçlıyorsak, öncelikle bilgiden ziyade karakterimizle onları etkilememiz gerekir (Erden, 2008). Özellikle küçük yaştaki bireyler ve öğrenciler için, öğretici pozisyonunda bulunan öğretmenlerde, mesleki becerilerden daha çok kişisel özelliklerin önemli olduğu anlaşılmıştır (Yarar ve Tekbıyık, 2009; Krzywacki, 2009). Eğitim bilimlerinde yapılan çalışmalar göstermektedir ki öğretmenlerin yeterlilikleri (kişisel ve mesleki) arttıkça daha nitelikli ve karakterli öğrenciler yetişebilmektedir (Gözütok, 1995; Gürkan, 1993; Mentiş Taş, 2004).

Kısacası, okullarda değer öğretimi yapılırken öğretmene önemli vazifeler düşmesinin yanında, öğretmenin bu değerlere kendisinin sahip olup olmadığı, bu konudaki bilgisi, entelektüel düzeyi, kendini geliştirme durumu, örtük programı yeri geldiğinde kullanması, kişiliği, saygınlığı, alanına olan hâkimiyeti vs. gibi konularda beraberinde önemini ortaya çıkarmaktadır (Ada, Baysal \& Korucu, 2005; Gözütok, 1995; Gürkan, 1993; Mentiş Taş, 2004). Çünkü kendisi hoşgörülü, dürüst, sorumlu, yardımsever, sabırlı, adaletli olmayan bir öğretmenin öğrencilerine bunları aşılamaya çalışması tuhaf olacaktır. Yararına ve gereğine inanmadan yapılan veya daha iyi nasıl yapabilirim düşüncesine sahip olmayan bir kişiden çok faydalı olması da beklenilemez (Özgüven, 1994:350).

$\mathrm{Bu}$ araştırmada değer eğitimi bağlamında önemli bir göreve sahip olan sınıf öğretmenlerinin o değere yönelik düşüncelerini ortaya çıkarmak ve o değer hakkındaki çağrışımlarını tespit etmek amacıyla önem arz etmektedir. Gerek zihin haritası gerekse değer eğitimi üzerine birçok araştırma olmasına rağmen bu ikisini birleştiren çalışmalar olamadığı için özgün değer taşımaktadır.

\subsection{Amaç}

$\mathrm{Bu}$ araştırma, gelecek nesillere etkilemede önemli bir yeri olan sınıf öğretmenlerinin değer eğitimine yönelik düşüncelerini ortaya çıkarmak ve bu düşüncelerini yansıttıkları zihin haritalarını yorumlamak amacıyla yapılmıştır. Bu amaç çerçevesinde aşağıdaki alt amaçlara cevap aranmıştır. 


\subsubsection{Alt Amaçlar}

1) Sınıf öğretmenlerinin değer eğitimiyle ilgili zihin haritaları nelerdir?

2) Sınıf öğretmenleri en çok önemsedikleri değer için kimden etkilenmiştir? Niçin?

3) Sınıf öğretmenleri en çok önemsedikleri değerin kimde olmasını ister? Neden?

4) Sınıf öğretmenleri en çok önemsedikleri değere kendileri sahip mi? Nasıl anlaşılır?

\section{YÖNTEM}

\subsection{Araştırmanın Deseni}

Sınıf öğretmenlerinin değer öğretimine ilişkin görüşlerini tespit etmek ve zihin haritalarını ortaya çıkarmak amacıyla yapılan bu araştırma nitel desene göre şekillendirilmiştir. $\mathrm{Bu}$ amaç doğrultusunda araştırmada nitel araştırma desenlerinden biri olan fenomonolojik yaklaşım kullanılmıştır. Fenomonolojik desenler, daha çok bireyin iç dünyasına, onların bilinç yapılarını belirlemeye dönüktür (Mayring, 2000). Fenomonolojik çalışmalardaki amaç, tek tek bireylerin bakış açılarından bakarak onların bireysel anlam yapılarını ve niyetlerini anlamaya çalışmaktır. Bu araştırmada da sınıf öğretmenlerinin değer öğretimine yönelik düşünceleri ve görüşleri belirlenmeye çalışıldığından fenomonolojik yaklaşım kullanılmıştır.

\section{2. Çalışma Grubu}

Araştırmanın çalışma grubunu, Isparta ilindeki sınıf öğretmenlerinden gönüllülük esasına göre rastgele seçilen 15 sınıf öğretmeni oluşturmaktadır. Araştırmada, Kolay ulaşılabilir durum örneklemesi kullanılmıştır. Çünkü bu yöntemde araştırmacı, yakın ve erişilmesi kolay olan bir durumu seçer (Şimşek ve Yıldırım, 2006). Araştırmanın çalışma grubunu oluşturan öğretmenlerin kişisel özellikleri aşağıda, Tablo 1'de gösterilmiştir.

Tablo 1

Katılımcıların Kişisel Özellikleri

\begin{tabular}{lll}
\hline Özellik & Düzey & Frekans \\
\hline Cinsiyet & Kadın & 11 \\
\cline { 2 - 3 } & Erkek & 4 \\
\hline Kıdem & $0-10$ yıl & 2 \\
\cline { 2 - 3 } & $11-20$ & 10 \\
\hline Medeni durum & 20 ve üstü & 3 \\
\hline Okuttukları sınıf düzeyi & Evli & 7 \\
\cline { 2 - 3 } & Bekâr & 4 \\
\cline { 2 - 3 } & $1 . \operatorname{sinıf}$ & 6 \\
\cline { 2 - 3 } & $2 . \sin ı f$ & 2 \\
\hline
\end{tabular}

\subsection{Veri Toplama Aracı}

Bu araştırmada veri toplama aracı olarak araştırmacı tarafından geliştirilen açık uçlu sorulardan oluşan yarı yapılandırıımış görüşme formu kullanılmıştır. Yarı yapılandırıımış görüşme formundaki soruların geçerliğini sınamak için eğitim bilimleri alanında çalışmaları bulunan farklı üniversitelerdeki farklı öğretim üyelerinin görüş ve değerlendirmelerine başvurulmuştur. Öğretim üyeleri görüşme formunu ifade ve içerik uygunluğu açısından değerlendirmiştir. Değerlendirme sonucunda ifade ve içerik uygunluğu açısından uygun görülen değişiklikler yapılarak yarı yapılandırılmış görüşme formuna son şekli verilmiştir.

Yarı yapılandırımış görüşme formu iki bölümden oluşmaktadır. Birinci bölümde katılımcıların kişisel özelliklerini (cinsiyet, kıdem, medeni durum, okuttuğu sınıf düzeyi ) tespit etmek amacıyla sorular sorulmuştur. İkinci bölümde ise katılımcıların görüşlerini öğrenmek 
amacıyla alt amaçlara uygun olarak açık uçlu sorular sorulmuştur. Ayrıca görüşme esnasında katılımcılara görüşme formuna zihin haritaları çizdirilmiş ve daha sonra bilgisayar ortamına aktarılarak analizi yapılmıştır.

Araştırmada kullanılan veri toplama aracının güvenirliği Miles ve Huberman formülü kullanılarak tespit edilmiştir. Araştırmanın güvenirliğini sağlamak amacıyla 4 uzman görüşüne başvurulmuştur. Bu işlemde araştırmacı ve uzman aynı temayı işaretlerse veya her ikisi de aynı temayı işaretlemezlerse bu durum uzmanlar arasında görüş birliği olarak kabul edilmekte; Eğer araştırmacı ve uzman farklı temaları işaretlerse bu durum görüş ayrılı̆̆ı olarak kabul edilmektedir (Miles \& Huberman, 1994). Araştırmanın güvenilirliği ise Güvenirlik=Görüş Birliği / (Görüş Birliği + Görüş Ayrılığı) formülü sonucunda en az \%70 düzeyinde güvenilirlik katsayısı ile ortaya konmaktadır (Miles \& Huberman, 1994). Bu araştırmaya özgü olarak gerçekleştirilen güvenirlik çalışmasında \%95 oranında bir uzlaşma (güvenirlik) sağlanmıştır.

\subsection{Verilerin analizi}

Araştırma verilerinin çözümlenmesinde betimsel analiz kullanılmıştır. Betimsel analizde edilen veriler, daha önceden belirlenen temalara göre özetlenmiş ve yorumlanmıştır. Elde edilen nitel verilerin sayısallaştırılması yoluna gidilerek veriler frekanslarla birlikte sunulmuştur. Bulguların sunumunda öğrencilerin görüşlerinden doğrudan alıntılar yapılmıştır. Betimsel analizde amaç, elde edilen bulguları düzenlenmiş ve yorumlanmış bir biçimde okuyucuya sunmaktır (Yıldırım ve Şimşek, 2006:224).

\section{BULGULAR}

Bu bölümde yarı yapılandırılmış görüşme formundan elde edilen veriler analiz edilerek bulgular ortaya konmuştur. Elde edilen bulgular tablolar halinde gösterilerek açıklanmaya çalışıımıştır. Her alt problem için analizler ayrı ayrı yapılmış ve belirtilmiştir. Görüşme formunda sorulan sorular açık uçlu olduğundan soruların analizlerinde bazı sınıf öğretmenlerinin görüş ve düşünceleri aynen kullanılmıştır.

\subsection{Birinci Alt Amaç İçin Bulgular}

Sınıf öğretmenlerinin değer öğretimine ilişkin düşüncelerini öğrenme amacıyla görüşme formunda katılımcılara 'Sizin için en önemli değer nedir ve bunun zihin haritasını çiziniz' sorusuna verdikleri cevaplar tabloda gösterilmiş ve her bir değerle ilgili zihin haritaları sırasıyla yorumlanmıştır. Tablo 2'de görüldüğü üzere katılımcı sınıf öğretmenleri 'en önemli değeri' farklı şekillerde önemsemişlerdir. Sınıf öğretmenlerinin görüşleri 9 gruba ayrılarak değerlendirilmiştir. En çok dürüstlük değeri dikkat çekmektedir.

Tablo 2

Sınıf Öğretmenlerinin En Fazla Önemsedikleri Değerler

\begin{tabular}{cc}
\hline Değerler & Frekans \\
\hline Dürüstlük & 5 \\
\hline Sevgi & 2 \\
\hline Saygı & 2 \\
\hline Empati & 1 \\
\hline Vicdan & 1 \\
\hline İilik & 1 \\
\hline Adalet & 1 \\
\hline Güven & 1 \\
\hline Merhamet & 1 \\
\hline
\end{tabular}

Değer, bir toplumun üyelerinin çoğunluğu tarafından doğru ve gerekli oldukları kabul edilen ortak düşünce, amaç, temel ahlâkî ilke ya da inançlardır. Araştırmada elde edilen 
bulgulara bakıldığında katılımcılar doğru ve gerekli olduğunu düşündükleri değerlere 'dürüstlük, sevgi, saygı, empati, vicdan, iyilik, adalet, güven, merhamet' gibi cevaplar vermişlerdir. 'Dürüstlük, sevgi ve saygı' değerleri en fazla önem verilen değerler arasındadır. Bu değerler çoğu değer sınıflamasında da yerini her zaman almıştır. (Lickona, 1991; Spranger, akt: Akbaş, 2004; Schwartz,1992; Güngör, 1998; Acat ve Aslan,2012; Nelson,1974, akt: Naylor ve Diem,1987). Aşağıda öğretmenlerin bu değerlere ilişkin zihin haritalarından her değer için birer örnek verilmiştir.

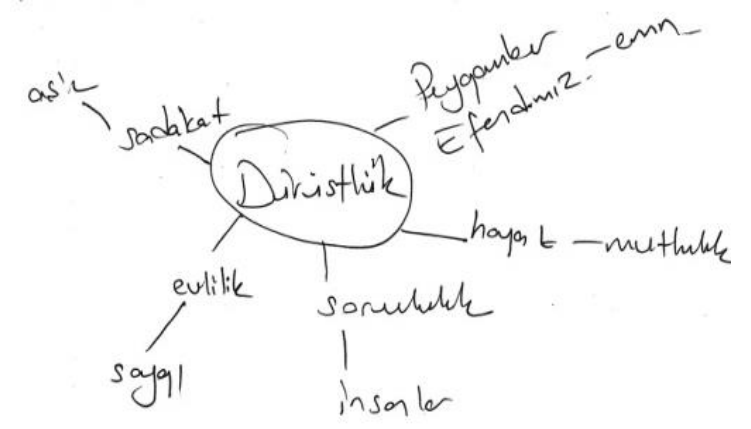

Şekil 1. Dürüstlük

Yukarıda Ö3 öğretmenine yönelik örnek bir zihin haritasına yer verilmiştir. Şekilde görüldüğü gibi merkezde yer alan dürüstlük değeri aslında içinde sadakat, saygı, sorumluluk, saygı gibi birçok değeri barındırmaktadır. Dürüstlüğün başta dini konularda olmak üzere hayatın çoğu bölümünde karşımıza çıkan bir olgu olduğunu söyleyebiliriz. Bir başka deyişle dürüstlüğün hayatımızı idame ettirmemiz ve mutlu olmamız için gerekli değerlerden biri olduğunu düşünebiliriz. Nitekim dürüst olmayan bir insan çoğu değerden de yoksun olacaktır.

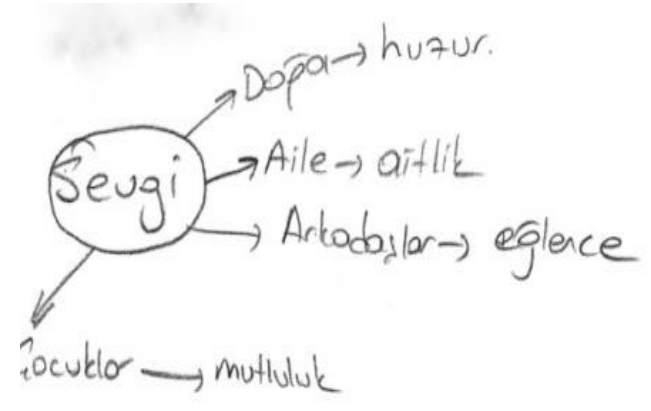

Şekil 2. Sevgi

Yukarıda Ö14 öğretmenine yönelik örnek bir zihin haritasına yer verilmiştir. Zihin haritasının merkezinde yer alan sevgi değeri, öğretmen için yakın çevresini ve doğayı çağrıştırmaktadır. Yakın çevremizle iyi ilişkiler içinde olmak ve doğayla barışık olmak, sevgi sahibi olmakla mümkündür denilebilir. Aynı şekilde sevgi sahibi olmayan bir birey, ailesiyle eşiyle, çocuklarıyla, arkadaşlarıyla iyi ilişkiler kuramayıp huzursuz ve mutsuz biri olabilir. Hangi dinden, hangi milletten ve hangi ırktan olursa olsun insanın doğası gereği bünyesinde bulundurması gereken sevgi duygusu, birçok araştırmacının değer sınıflamasında dini değerler arasında yer almıştır. 


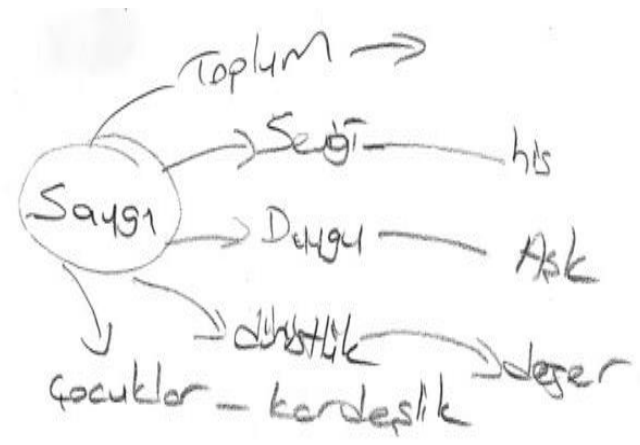

Şekil 3. Saygı

Yukarıda Ö13 öğretmenine yönelik örnek bir zihin haritasına yer verilmiştir. Bu zihin haritasından da anlaşılacağı gibi saygı değeri sevgi, aşk, dürüstlük, kardeşlik gibi birçok değeri içinde barındıran evrensel bir değerdir diyebiliriz. Saygısını yitirmiş bir birey aynı zamanda bu değerlerden yoksun olmaktadır. Sağıklı ilişkiler kurmak ve devamında sevgi, kardeşlik, dürüstlük gibi duyguların hayatında olması isteyen herkesin benimsemesi gereken, evrensel değerlerden biri olan saygı, birçok değer sınıflamasında yer almıştır (Schwartz, 1992; Kale, 2004; Ercan, 2001; Canatan, 2004; Gündüz, 2016).

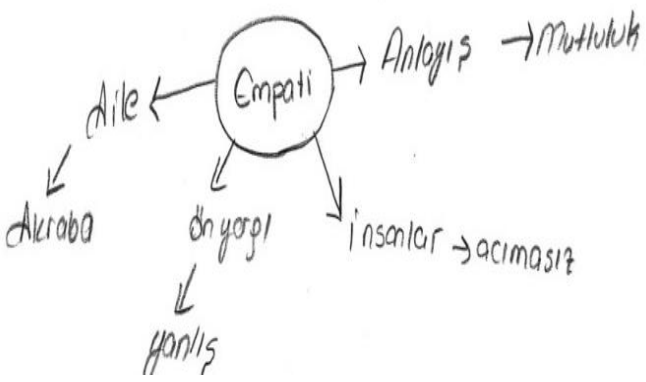

Şekil 4. Empati $(n=1)$

Yukarıda Ö12 öğretmenine yönelik örnek bir zihin haritasına yer verilmiştir. Empati değerini sadece bir sınıf öğretmeni ifade etmiştir. Bu öğretmenin merkezde bulunan empati değerinden empati yeteneğine sahip insanların anlayışı ve mutlu bireyler olacağı, aynı şekilde empati yeteneği sahip olmayan bireylerin önyargılı ve acımasız olabileceği anlaşılmaktadır. Empati kurmaya öncelikle aile ve akraba gibi en yakın çevreden başlanırsa, daha sağlıklı ilişkiler kurulabilir.

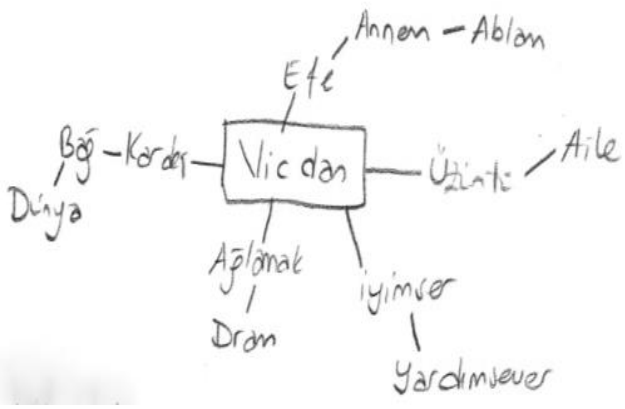

Şekil 5. Vicdan $(n=1)$

Yukarıda Ö15 öğretmenine yönelik örnek bir zihin haritasına yer verilmiştir. Vicdan değerini sadece bir sınıf öğretmeni ifade etmiştir. Bu öğretmenin zihin haritasından anlaşılacağı gibi merkezde bulunan vicdan değeri asında kendi içerisinde iyimserlik, yardımseverlik gibi 
değerleri de barındırdığı görülmektedir. Vicdan değerinin en başta aile bağlarıyla karşımıza çıktığını söylenebiliriz. Ayrıca bu zihin haritasından, çevremizde vicdan değerine sahip olmayan insanların kendimizi üzgün hissetmemizi sağladığını hatta ağlamak gibi olumsuz durumları yaşattı̆̆ını anlayabiliriz.

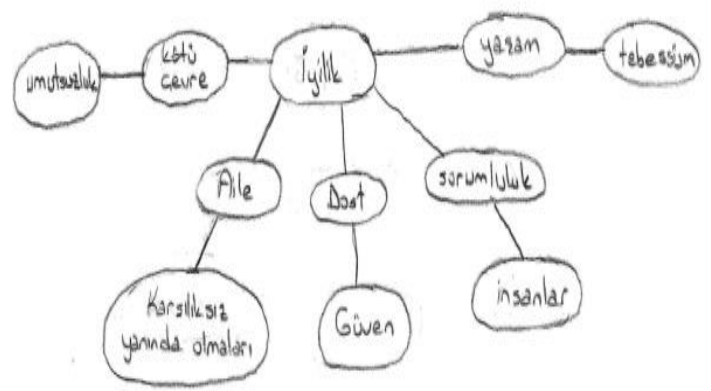

Şekil 6. İyilik $(\mathrm{n}=1)$

Yukarıda Ö1 öğretmenine yönelik örnek bir zihin haritasına yer verilmiştir. İyilik değerini sadece bir sınıf öğretmeni ifade etmiştir. Bu öğretmenin zihin haritasından anlaşılacağı gibi iyilik değerinin başta aile ve arkadaş çevresi olmak üzere hayatımızın her yerinde karşımıza çıktığını söyleyebiliriz. Bir ailede karşılıksız ilişkiler ve dostlar arası güven ilişkisi, iyilik değeri üzerine kurulur denilebilir. Bu zihin haritasından, hayatının merkezine iyilik değerini yerleştiren birinin, insanlarla iyi ilişkiler kurup mutlu olabileceği anlaşılmaktadır.

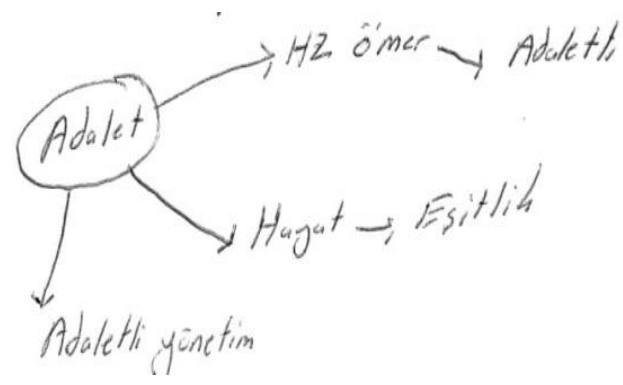

Şekil 7. Adalet $(\mathrm{n}=1)$

Yukarıda Ö6 öğretmenine yönelik örnek bir zihin haritasına yer verilmiştir. Adalet değerini sadece bir sınıf öğretmeni ifade etmiştir. Bu öğretmenin zihin haritasından anlaşılacağı gibi bireylerin adalet değeri konusunda, eski zamanlarda yaşamış, adalet değerini hayatına geçirmiş, örnek hayatlar yaşamış sahabelerden etkilenebileceği anlaşılıyor. Adaletli bir birey olmak için dini konuları hayatımıza geçirip bu değer için en iyi örnek teşkil edecek kişilerin hayatlarına bakabiliriz.

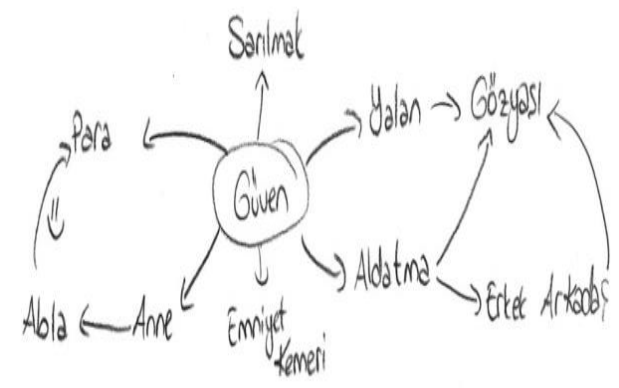

Şekil 8. Güven ( $\mathrm{n}=1)$

Yukarıda Ö10 öğretmenine yönelik örnek bir zihin haritasına yer verilmiştir. Güven değerini sadece bir sınıf öğretmeni ifade etmiştir. Bu öğretmenin zihin haritasından anlaşılacağı 
gibi güven değerine anne, abla, erkek arkadaş gibi yakın ilişkilerde bulunduğumuz kişilerden beklediğimiz anlaşılabilir. Aynı zamanda sadece bireylerin değil emniyet kemeri gibi cansız varlıklarında bizlere güven verebileceği anlaşılmaktadır. Güvensizlik durumunda da yalan, aldatma, gözyaşı gibi olumsuz durumlarla karşılaşabiliriz.

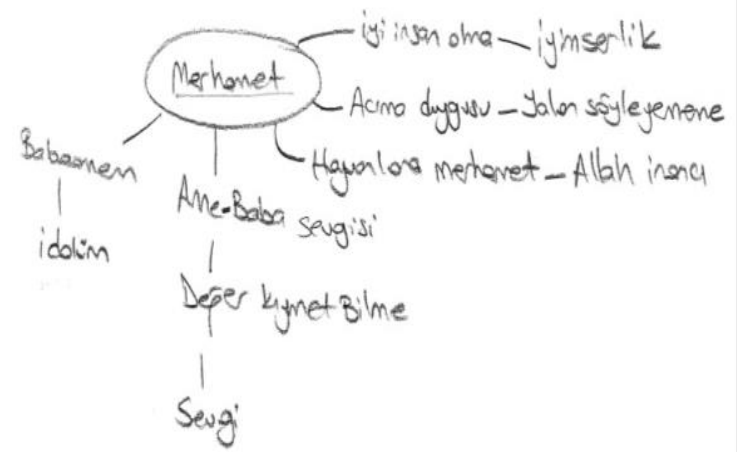

Şekil 9. Merhamet $(n=1)$

Yukarıda Ö2 öğretmenine yönelik örnek bir zihin haritasına yer verilmiştir. Merhamet değerini sadece bir sınıf öğretmeni ifade etmiştir. Bu öğretmenin zihin haritasından anlaşılacağı gibi merhamet kelimesine bakıldığında, diğer değerlerde olduğu gibi, bu değerin de içinde sevgi, inanç, iyimserlik, değer verme gibi birçok değeri barındırdığı söylenebilir. İçinde acıma duygusu olan birinin yalan söyleyemeyeceği, gerçek manada Allah inancı olan birinin hayvanlara karşı merhametli olabileceği, merhamet duygusuna sahip birinin iyimserlik duygusuna da sahip olabileceği söylenebilir.

\section{2. İkinci Alt Amaç İçin Bulgular}

Sınıf öğretmenlerine en çok önemsedikleri değer için kimden etkilendikleri ve sebebinin sorulduğu bu bölümde sınıf öğretmenlerinin verdikleri cevaplar aşağıdaki tabloda gösterilmiştir.

Tablo 3

Katılımcıların Kimden Etkilendiği ve Sebebi

\begin{tabular}{llll}
\hline Öğretmen & Değer & Kimden etkilendi? & \\
\hline Ö1 & İyilik & Çocuklar & Bilinçli olarak hiç zaman kötülük yapmazlar \\
\hline Ö2 & Merhamet & Ailem & $\begin{array}{l}\text { Yardıma muhtaç insanlara, iyi-kötü ayırt } \\
\text { etmeksizin yardım ederler }\end{array}$ \\
\hline Ö3 & Dürüstlük & $\begin{array}{l}\text { Peygamber } \\
\text { efendimiz }\end{array}$ & Hiçbir koşulda yalan söylememiştir \\
\hline Ö4 & Dürüstlük & $\begin{array}{l}\text { Peygamber } \\
\text { efendimiz }\end{array}$ & Şaka dahi olsa asla yalan söylemezdi \\
\hline Ö5 & Sevgi & Hz. Rabia & Çıkar gözetmeksizin, hakkını vererek sevmiştir \\
\hline Ö6 & Adalet & Hz. Ömer & Hiçbir zaman dürüstlüğünden ödün vermemiştir \\
\hline Ö7 & Dürüstlük & Atalarım & $\begin{array}{l}\text { Düşman devletlere karşı her şeylerini kaybetmiş } \\
\text { fakat dürüstlüklerinden ödün vermemişlerdir }\end{array}$ \\
\hline Ö8 & Saygı & Öğretmenlerim & Beni hiç rencide etmediler \\
\hline Ö9 & Dürüstlük & Ailem & Beni hiçbir zaman yanıltmadılar \\
\hline Ö10 & Güven & Babam & Ona hiç güvenemedim \\
\hline Ö11 & Dürüstlük & Annem & Hiçbir zaman menfaati için değişmemiştir \\
\hline Ö12 & Empati & Hz. Mevlana & $\begin{array}{l}\text { Her zaman sözleriyle bu şekilde daha mutlu } \\
\text { olacağımı hissettirdi }\end{array}$ \\
\hline & & & \\
\hline
\end{tabular}




\begin{tabular}{llll}
\hline Ö13 & Saygı & Ailem & Hiçbir zaman saygıda kusursuzluk yapılmadı \\
\hline Ö14 & Sevgi & Babam & Yanında huzur buluyorum \\
\hline Ö15 & Vicdan & Hayvanlar & Çok savunmasızlar \\
\hline
\end{tabular}

Sınıf öğretmenlerinin vermiş olduğu görüşler doğrultusunda tabloda yer alan bilgilere bakıldığında sınıf öğretmenlerinin en fazla önemsedikleri değer konusunda etkilendikleri kişiler çeşitlilik göstermektedir. Anne, baba, çocuklar, aile, öğretmen gibi yakın ilişkiler kurulan kişilerden etkilendikleri gibi aynı zamanda eski çağlarda yaşamış, örnek hayatlar sunan $\mathrm{Hz}$. Muhammed, Hz. Rabia, Hz. Ömer, Hz. Mevlana gibi dini kişiliklerden de etkilendikleri görülmektedir. Farklı olarak atalarımızdan ve hayvanlardan etkilendiğini düşünen öğretmenlerde vardır.

Bu kişilerden neden etkilendikleri sorulduğunda cevapların genellikle aynı gerekçelerle verildiği görülmektedir. Öğretmenlerin önem verdiği değerlerin, etkilendikleri kişiler tarafından hayatlarına en iyi şekilde geçirdikleri ve bu kişilerin birer örnek teşkil ettikleri görülmektedir. Mesela merhamet konusunda ailesinden etkilenen bir öğretmen ailesinin her durumda yardıma muhtaç insanlara yardım ettiğinden bahsetmiştir. Aynı şekilde dürüstlük konusunda $\mathrm{Hz}$. Muhammed, adalet konusunda $\mathrm{Hz}$. Ömer, hoşgörü konusunda $\mathrm{Hz}$. Mevlana toplumda her zaman birer idol olarak benimsenmiştir. İstisna olarak Ö10 öğretmeni, babası kendisine kötü örnek olduğu için babasından etkilendiğini belirtmiştir.

\section{3. Üçüncü Alt Amaç İçin Bulgular}

Sınıf öğretmenlerine en çok önemsedikleri değerin kimde olmasını istedikleri ve nedeni soruldu. Öğretmenlerin verdiği cevaplar aşağıda Tablo 4'deki gibidir.

Tablo 4

Katılımcıların En Çok Önemsedikleri Değerin Kimde Olmasına Yönelik Görüşleri

\begin{tabular}{|c|c|c|c|}
\hline Öğretmen & Değer & Kimde olmasını istersin & Neden? \\
\hline Ö1 & İyilik & Bana taciz eden o şerefsizde & $\begin{array}{l}\text { Canımın ne kadar yandığını bilsin, kötülüğün } \\
\text { bir tercih olduğunu bilsin isterdim }\end{array}$ \\
\hline Ö2 & Merhamet & $\begin{array}{l}\text { Zalimlerde, hayvanlara } \\
\text { eziyet edenlerde }\end{array}$ & Böylece dünya daha yaşanır bir hal alır \\
\hline Ö3 & Dürüstlük & Çocuğumda & O beni temsil ediyor \\
\hline Ö4 & Dürüstlük & En çok sevdiğim insanda & Ömür paylaşacağım \\
\hline Ö5 & Sevgi & Bütün insanlarda & Diğer bütün değerler ardı sıra gelir \\
\hline Ö6 & Adalet & Eşimde & İnsanı rezilde eden, vezirde eden kadındır \\
\hline Ö7 & Dürüstlük & Toplumumuzda & \\
\hline Ö8 & Saygı & Eşimde & Hayatımda o beni temsil edecek \\
\hline Ö9 & Dürüstlük & Milletimde & $\begin{array}{l}\text { Daha mutlu ve birbirine bağlı bir millet } \\
\text { olurduk }\end{array}$ \\
\hline Ö10 & Güven & Henüz olmayan eşimde & $\begin{array}{l}\text { Hayatımın büyük bir bölümünü onunla } \\
\text { geçireceğim }\end{array}$ \\
\hline Ö11 & Dürüstlük & Eşimde & Beni de evlatlarımı da eşim yönlendirir \\
\hline Ö12 & Empati & Bütün insanlarda & Herkeste olmalı ki önyargılar ortadan kalksın \\
\hline Ö13 & Saygı & Çocuğumda & Yaşam boyu beni temsil edecek \\
\hline Ö14 & Sevgi & Çocuklarımda & Sevgi dolu insan kötülük yapmaz \\
\hline Ö15 & Vicdan & $\begin{array}{l}\text { Anne, baba ve her türlü } \\
\text { eğitimcilerde, bakıcılarda }\end{array}$ & Nasıl yetiştirirsen öyle gider \\
\hline
\end{tabular}

Sınıf öğretmenlerinin vermiş olduğu görüşler doğrultusunda tabloda yer alan bilgilere bakıldığında öğretmenlerin en fazla önemsedikleri değerin en çok olmasını istediği kişiler 
çoğunlukla 'eşimde'(n=5) ve 'çocuğumda'(n=3) olmuştur. Bunun yanında 'toplumumuzda','milletimde', 'bütün insanlarda', 'anne, baba ve her türlü eğitimcilerde, bakıcılarda' şeklinde bir çoğunluğu kapsayan cevaplarda olmuştur. Bu kategorilere farklı olarak 'bana taciz eden o şerefsizde' ve 'zalimlerde, hayvanlara eziyet edenlerde' şeklinde cevaplarda gelmiştir.

Neden bu kişilerde olması gerektiği sorulduğunda 'eşimde' ve 'çocuğumda' diyenlerin cevapları benzerlik göstermektedir. 'Ömür paylaşacağım' 'Hayatımın büyük bir bölümünü onunla geçireceğim' 'Hayatımda o beni temsil edecek' 'Beni de evlatlarımı da eşim yönlendirir' 'Yaşam boyu beni temsil edecek' şeklinde birbirine benzer cevapların verildiği görülmektedir. Yine aynı şekilde bir çoğunluğu kapsayan 'toplumumuzda','milletimde' diyenlerinde verdiği cevaplar kendi içinde benzerlik göstermektedir. 'Nasıl yetiştirirsen öyle gider', 'Herkeste olmalı ki önyargılar ortadan kalksın', 'Diğer bütün değerler ardı sıra gelir', 'Böylece dünya daha yaşanır bir hal alır' şeklinde aynı mantık çerçevesinde birbirine yakın cevaplar verildiği görülmektedir.

\subsection{Dördüncü Alt Amaç İçin Bulgular}

Sınıf öğretmenlerinin en çok önemsedikleri değere kendilerinin sahip olup olmadıkları ve bunu nasıl anladıkları sorulduğunda vermiş oldukları cevaplar aşağıdaki tabloda gösterilmiştir.

Tablo 5

Katılımcıların Bu Değerlere Sahip Olmaya Yönelik Görüşleri

\begin{tabular}{|c|c|c|c|}
\hline Öğretmen & Değer & Kendisi sahip mi? & Nasıl anlarsın? \\
\hline Ö1 & İyilik & İyiyim & $\begin{array}{l}\text { Bana zarar veren, hayatımı değiştiren, beni ilaçlara } \\
\text { bağımlı kılan birine rağmen iyiliği bırakmadım }\end{array}$ \\
\hline Ö2 & Merhamet & Merhametliyim & $\begin{array}{l}\text { Hayvan severim. Yolda sokakta sakat ya da ölmüş } \\
\text { hayvan görsem dayanamam, bakamam. Hatta benimde } \\
\text { bir hayvanım var. }\end{array}$ \\
\hline Ö3 & Dürüstlük & Değilim & Çünkü bazen kendimi bile kandırıyorum. \\
\hline Ö4 & Dürüstlük & Dürüstüm & $\begin{array}{l}\text { Karşımdaki insanın cevabından emin olana kadar } \\
\text { sorgularım }\end{array}$ \\
\hline Ö5 & Sevgi & İnsanları severim & $\begin{array}{l}\text { Fazlasıyla hoşgörülü olduğumu ve yaratılana saygı } \\
\text { duyduğumu düşünüyorum. }\end{array}$ \\
\hline Ö6 & Adalet & Dürüstüm & $\begin{array}{l}\text { Her şeyi olduğu gibi kabul edip çekinmeden doğruları } \\
\text { söylerim. }\end{array}$ \\
\hline Ö7 & Dürüstlük & Dürüstüm & $\begin{array}{l}\text { Dürüst olduğumu düşünüyorum ama yanlışlarımda } \\
\text { vardır mutlaka. }\end{array}$ \\
\hline Ö8 & Saygı & Saygılıyım & Küçük bir çocuktan bile özür dilerim. \\
\hline Ö9 & Dürüstlük & Değilim & Bazen tatlı yalanlar söylüyorum. \\
\hline Ö10 & Güven & $\begin{array}{l}\text { Güvenilirim, ama } \\
\text { her zaman değil }\end{array}$ & $\begin{array}{l}\text { Biri canımı acıttıysa bana güvenmesin. Kötülüğe iyilik er } \\
\text { kişinin harcıdır. Ben o kadar olgun değilim. }\end{array}$ \\
\hline Ö11 & Dürüstlük & Tamamen değilim & $\begin{array}{l}\text { Karşımdakini kırmaktan korkuyorum. Fakat kendi } \\
\text { içimdeki değerlendirmelerimi dürüstçe yapıyorum. }\end{array}$ \\
\hline Ö12 & Empati & Empati kurarım & Ön yargılı değilim. \\
\hline Ö13 & Saygı & Saygılıyım & Aileme ve çevreme karşı her zaman saygı duyuyorum. \\
\hline Ö14 & Sevgi & Çoğunlukla evet & İnsanları mutlu etmeyi severim. \\
\hline Ö15 & Vicdan & Vicdanlıyım & Çünkü hemen etkilenirim. \\
\hline
\end{tabular}

Sınıf öğretmenlerinin vermiş olduğu görüşler doğrultusunda tabloda yer alan bilgilere bakıldığında öğretmenlerin en fazla önemsedikleri değerin kendilerinde olup olmadığı sorulduğunda 10 kişi olumlu, 2 kişi olumsuz cevap vermiştir. 3 kişi de 'Çoğunlukla evet', 'Güvenilirim, ama her zaman değil' 'Tamamen değilim' şeklinde arada bir cevap vermiştir. 
Öğretmenlerin büyük bir çoğunluğu, en fazla önemsedikleri değerin kendilerinde olduğunu düşünmektedir.

Bu değerlerin kendilerinde olup olmadığını nasıl anladıkları sorulduğunda olumlu cevap veren öğretmenlerin verdiği cevaplardan bu değerleri kendi hayatlarına geçirdiklerini görmekteyiz. 'Saygııııım çünkü aileme ve çevreme karşı her zaman saygı duyuyorum', 'Merhametliyim çünkü hayvan severim', 'Dürüstüm çünkü her şeyi olduğu gibi kabul edip çekinmeden doğruları söylerim' şeklindeki cevaplardan da bunu anlamaktayız. Aynı şekilde olumsuz ve arada cevaplar veren öğretmenlerin de en fazla önem verdikleri değeri hayatlarına tam olarak geçirmediklerini görmekteyiz. 'Tamamen dürüst değilim çünkü karşımdakini kırmaktan korkuyorum', 'Güvenilirim, ama her zaman değil. Biri canımı acıttıysa bana güvenmesin' şeklindeki cevaplardan da öğretmenlerin bu değerleri hayatlarına geçirmediklerini anlaşılmaktadır.

\section{SONUÇ, TARTIŞMA VE ÖNERILER}

Gelecek nesillere iz bırakmada önemli bir yeri olan sınıf öğretmenlerinin değer öğretimine yönelik düşüncelerini ortaya çıkarmak ve bu düşüncelerini yansıttıkları zihin haritalarını yorumlamak amacıyla 15 sınıf öğretmenine uygulanan yarı yapılandırılmış görüşme formları ile elde edilen bulgular neticesinde aşağıdaki sonuçlara ulaşıımıştır:

Araştırmada sınıf öğretmenlerinin zihin haritalarından ortaya çıkan bulgulara göre öğretmenlerin değer öğretiminde en fazla önemsedikleri değerler 'dürüstlük' $(n=5)$, 'sevgi' $(n=2)$ ve 'saygı' $(n=2)$ olmuştur. Bu değerlerin yanında empati, vicdan, iyilik, adalet, güven, merhamet' gibi evrensel değerlerde cevap olarak gelmiştir. Bu değerler bireyi mutlu eden, yaşama amacını oluşturan, çevresindekilerle yakın ilişkiler içerisinde bulunmasını sağlayan, kişilik ve karakter oluşturmada büyük önem arz eden ve çoğu bireyde olması gereken değer algılarıdır. Yapılan değer sınıflamalarında bu değerler her zaman önemini korumuştur (Lickona, 1991; Rokeach,1973; Schwartz, 1992; Güngör, 1998; Kale, 2004; Ercan, 2001; Canatan, 2004; Acat ve Aslan, 2012; Gündüz, 2016). Bu değerler her insan için farklı anlamlar ifade etse de toplumun önem verdiği birleştirici değerlerdir. Her insanın aynı değere aynı anlamı da yüklemesi beklenemez. Çünkü geçmiş yaşantılar, etkileşime geçilen kişiler, cinsiyet, kültür gibi unsurlar insanların duygularını şekillendirir. Nitekim öğretmenlerin değerlere yüklediği anlamlar ve çağrışımlarda farklılık göstermektedir. Bu durum öğretmenlerin öğreteceği değere ve öğretme şekline yansıyacaktır.

Öğretmenlere önemsedikleri değer için en çok kimden etkilendikleri sorulduğunda en fazla 'ailem' ( $n=3)$, 'babam' ( $n=2)$ ve 'peygamber efendimiz' $(n=2)$ gibi cevaplar gelmiştir. Bu cevaplar kişilerin değer algısının farklı durumlardan beslendiğini doğrulamaktadır. Bu araştırma göstermiş̧ir ki bireyler en fazla doğup büyüdüğü, yetiştiği aile ortamından etkilenmektedir. Tutum ve değerlerin geliştirilmesi ilk olarak okul ve sınıf dışında karşılaşılan aile ve akraba gibi öğrenme ortamlarında meydana gelir (Seefeldt, 2004). Ayrıca Hz. Muhammed cevabını verenlerin yanında $\mathrm{Hz}$. Rabia, $\mathrm{Hz}$. Ömer, $\mathrm{Hz}$. Mevlana gibi dini kişiliklerden de etkilendiklerini ifade eden öğretmenler de var. Bireyler değer eğitimi konusunda ilk olarak aile ortamından etkilenseler de zamanla hayat hikâyelerini öğrendikleri, dini konuları hayatına tam anlamıyla geçirmiş dini kişiliklerden de etkilenebilmektedir. Farkı araştırmacılar tarafından yapılan birçok değer sınıflamasında, dini değerler her zaman yerini almıştır (Lickona, 1991; Spranger, akt: Akbaş, 2004; Schwartz,1992; Güngör, 1998; Acat ve Aslan,2012).

Sınıf öğretmenlerine en fazla önemsedikleri bu değerin en çok olmasını istedikleri kişiler sorulduğunda gelen cevaplar çoğunlukla 'eşim' $(n=5)$ ve 'çocuğum' ( $n=3)$ olmuştur. Buradan da anlaşılacağı gibi mutlu, huzurlu ve sağlıklı bir toplum olmanın ilk yolu aileden geçmektedir. Nitekim değer eğitiminin ilk başladığı ve en önemli olduğu yer de ailedir. Daha 
sonra ise okulda bu görevi sınıf öğretmenleri devralmaktadır (Ada, Baysal ve Korucu, 2005; Lovat, 2007; Bryk ve Schneider, 2002; Snook, 2007).

Öğretmenlere en fazla önemsedikleri değerin kendilerinde olup olmadığı sorulduğunda, 10 kişi olumlu, 2 kişi olumsuz cevap vermiştir. 3 kişi de 'Çoğunlukla evet', 'Güvenilirim, ama her zaman değil', 'Tamamen değilim' şeklinde arada cevaplar vermiştir. Marcus ve Fritzer'e (1999) göre değer eğitimi çalışmalarının hedefe ulaşabilmesi için, aileler değer eğitiminin gerekli olduğuna inanmalı ve öğrencilere verilmek istenen değerler de herkesçe benimsenen değerler olmalıdır. Çünkü kendisinin hoşgörü, dürüstlük, sorumluluk, yardımseverlik, sabırlılık, adaletlilik gibi değerleri taşımayan bir ebeveynin veya öğretmenin çocuğa bu değerleri aşılamaya çalışmasını beklemek zor olacaktır. Yararına ve gerekliliğine inanmadan yapılan veya daha iyisini nasıl yapabilirim düşüncesine sahip olmayan öğretmenden çok faydalı işlerde bulunması da beklenemez (Özgüven, 1994).

Sonuç olarak bu çalışma göstermiştir ki araştırmaya katılan öğretmenlerin büyük çoğunluğu değer eğitimi bağlamında bilinçlidir. Çizmiş oldukları zihin haritaları göz önünde bulundurulduğunda, önemsedikleri değerlere yönelik algı ve çağrışımları yapacakları değer eğitimi hakkında ipuçları vermektedir. Öğretmenlerin değer öğretimine yönelik tutum ve davranışları, o değerin daha nitelikli öğretilmesi bakımından önemlidir.

\section{KAYNAKLAR}

Acat, M. B ve Aslan, M.(2012). Yeni Bir Değer Sınıflaması ve Bu Sınıflamaya Bağıı Olarak Öğrencilere Kazandırıması Gereken Değerler, Kuram ve Uygulamada Eğitim Bilimleri (KUYEB), 12(2), 1460-1474.

Ada, S., Baysal, Z. N ve Korucu, S. (2005). Sınıf öğretmenlerinin sınıf içi olumsuz davranışlara gösterdikleri tepkilerin karakter eğitimi ve 2005 ilköğretim programı açısından değerlendirilmesi. Değerler Eğitimi Dergisi, 3(10), 7-18.

Akbaş, O.(2004). Türk Milli Eğitim Sisteminin Duyuşsal Amaçlarının Illköğretim II. Kademedeki Gerçekleşme Derecesinin Değerlendirilmesi, (Yayınlanmamış Doktora Tezi), Gazi Üniversitesi, Ankara.

Akbaş, O. (2015). Sosyal bilgilerde değerler ve öğretimi. B. Tay, ve A. Öcal (Ed.) içinde, Özel öğretim yöntemleriyle sosyal bilgiler öğretimi (s. 343-370). Ankara: PegemA.

Arslan, A. (2012). Felsefeye giriş. Ankara: Adres.

Ateş, F. (2013). ilkokul ve ortaokul öğretmenlerinin değerler eğitimi ve uygulamalarına yönelik görüşleri üzerine nitel bir araştırma. (Yayımlanmamış yüksek lisans tezi), Yeditepe Üniversitesi, İstanbul.

Balaban-Salı, J. (2004). Öğrenmede güdülenme, Yıldız Kuzgun ve Deniz Deryakulu (Ed.), Eğitimde Bireysel Farklılıklar içinde (s.167-197). Ankara: Nobel.

Balım, A. G., Aydın, G., Türkoğuz, S., Evrekli, E ve İnel, D.(2011). Fen ve Teknoloji Öğretmenlerine Yönelik Teknoloji Destekli Zihin Haritaları Uygulamaları, Batı Anadolu Eğitim Bilimleri Dergisi, 2(4), 91-100

Brinkmann, A.(2003). Graphical Knowledge Display-Mind Mapping and Concept Mapping as Efficient Tools in Mathematics Education, Mathematics Education Review, 16, 35-48 
Bryk, A and Schneider, B. (2002).Trust in Schools: A Core Resource for Improvement, New York: Russell Sage Foundation

Buzan, T and Buzan, B.(2010). Zihin Haritaları-The Mind Map Book Unlock Your Creativity, Boost Your Memory, Change Your Life, İstanbul: Alfa Yayınları

Caine, R. N and Caine, G. (2002). Beyin Temelli Öğrenme, Ankara: Nobel Yayınları

Canatan, K. (2004). Avrupa Birliği Ülkelerinde Değerler Yönelimi, Değerler Eğitimi Dergisi, 2(78), 41-63

De La Cruz-Bechtel, R. M. (2008). Unlocking creativity in the classroom. Unpublished Dissertation for the Master of Arts in Teaching, The University of Texas at El Paso, USA

Derelioğlu, Y. (2005). Hayat bilgisi ve Sosyal Bilgiler öğretimi dersinde akıl haritasının kullanımı. Eğitimde lyi Örnekler Konferansı, (15-16 Ocak), Sabancı Üniversitesi, İstanbul.

Doğanay, A. (2007). Değerler eğitimi. C. Öztürk (Ed.), Hayat bilgisi ve sosyal bilgiler öğretimi içinde (s. 256-284). Ankara: PegemA.

Doğanay, H. (2014). Coğrafya öğretim yöntemleri (5. Baskı). Ankara: PegemA.

Dönmez, B ve Cömert, M. (2007). İlköğretim okulu öğretmenlerinin değer sistemleri. Değerler Eğitimi Dergisi, 5(14), 29-59.

Ercan, i. (2001). Illköğretim Sosyal Bilgiler Programında Ulusal ve Evrensel Değerler, (Yayınlanmamış Yüksek Lisans Tezi), On sekiz Mart Üniversitesi, Çanakkale.

Erden, M. (2008). Sınıf Yönetimi, Ankara: Arkadaş

Evrekli, E and Balım, A. G.(2010). Fen Ve Teknoloji Öğretiminde Zihin Haritası ve Kavram Karikatürü Kullanımının Öğrencilerin Akademik Başarılarına ve Sorgulayıcı Öğrenme Becerileri Algılarına Etkisi, Batı Anadolu Eğitim Bilimleri Dergisi, 1(2), 76-98

Evrekli, E.(2010). Fen ve Teknoloji Öğretiminde Zihin Haritası ve Kavram Karikatürü Etkinliklerinin Öğrencilerin Akademik Başarılarına ve Sorgulayıcı Öğrenme Beceri Algılarına Etkisi (Yayınlanmamış Yüksek Lisans Tezi), Dokuz Eylül Üniversitesi, İzmir

Farrand, P., Hussain, F. and Hennessy, E.(2002). The Efficacy of the Mind Map Study Technique, Medical Education, 36, 426-431

Fidan, E. K.(2012). Fen ve Teknoloji Dersinde Bilgisayar Destekli Zihin Haritası Oluşturmanın Öğrencilerin Akademik Başarısına, Tutumlarına ve Kalıcılığa Etkisi (Yayınlanmamış Yüksek Lisans Tezi), Fırat Üniversitesi, Elazığ.

Fidan, N and Erden, M. (2001). Eğitime giriş. İstanbul: Alkım.

Gözütok, F. D. (1995). Öğretmenlerin demokratik tutumları, Ankara: Ekin.

Gündüz, M. (2016). Classifying Values by Categories. Journal of Education and Training Studies, 4(10), 212-220.

Güngör, E.(1998). Değerler Psikolojisi Üzerine Araştırmalar, İstanbul: Ötüken.

Gür, S ve Bütüner, H.(2006). Development of the Attitude Scale toward Mind Mapping Technique which is Used in Mathematics, Elementary Education Online, 5(2), 1305-3515 
Gürkan, T. (1993). Ilkokul öğretmenlerinin öğretmenlik tutumları ile benlik kavramları arasındaki ilişki, Ankara: Sevinç Matbaası.

Hyerle, D. (1996). Thinking Maps: Seeing is Understanding. Educational Leadership, 53(4), 8589.

Kale, N.(2004). Nasıl Bir Değerler Eğitimi, Değerler ve Eğitimi Uluslararası Sempozyumu, Değerler Eğitimi Merkezi Yayınları, İstanbul.

Karataş, S.(2010). Bilgisayar ve Öğretim Teknolojileri (BÖTE) Öğretmen Adaylarının Mesleklerine illişkin Zihin Haritalarının Analizi (Gazi Üniversitesi Örneği), Ahi Evran Üniversitesi Eğitim Fakültesi Dergisi, 11,1, 159-173

Ladge, D. (2002). How We Write? London, England: Routledge.

Lickona, T. (1991). Educating for Character: How our schools can te-ach respect and responsibility. Newyork: Bantam Books.

Ling, C. W.(2004). The Effectiveness of Using Mind Mapping Skills in Enhancing Secondary One and Secondary Four Students' Writing in CMI School, Master Thesis, The University of Hong Kong, China

Liu, K. W.(1995). The Study of the Effects of Mind Mapping Program on the Linguistic Creativity Ability of Fifth-Grade Students in Elementary School, Yüksek Lisans Tezi, National Chiayi University, Department of Special Education, Chiayi City, Taiwan

Lovat, T. (2007). Values Educatıon: The Missing Link in Quality Teching and Effective Learning, D.N. Aspin and J.D. Chapman (eds.), Values Education and Lifelong Learning, pp. 199210

Marcus, M ve Fritzer, P. (1999). Moral Education as Public Issue. Contemporary Education. 70(3), 44-45.

Mayring, R. (2000). Nitel sosyal araştırmaya giriş (Çev., A. Gümüş \& M.S. Durgun), Adana: Baki Kitapevi.

Mentiş Taş, A. (2004). Sosyal bilgiler öğretmenliği eğitimi program standartlarının belirlenmesi, Eğitim Bilimleri Fakültesi Dergisi, 37(1), 28-51.

Miles, M.B and Huberman, A.M. (1994). Qualitative dataanalysis, Thousand Oaks, CA: Sage.

Milli Eğitim Bakanlığı (2004). İlköğretim sosyal bilgiler ders programı (4 ve 5.Sınıflar), Ankara.

Naylor, D, T and Diem, R. (1987). Elementary and middle school social studies, New York: Random House

Özen, Y., Güleryüz, K and Bulut-Özen, H. (2012). Illköğretim 1-3 sınıf Hayat Bilgisi, 4-5 sınıf Sosyal Bilgiler dersindeki değerler ve değerler eğitiminin incelenmesi. Eğitim ve Öğretim Araştırmaları Dergisi, 1(4), 277-286.

Özgüven, İ. E. (1994). Psikolojik testler, Ankara: Yeni Doğuş Matbaası.

Schwartz, S. H. (1992). Universals in the content and structure of values: Theoretical advances and emprical tests in 20 countries. Ad-vances in Experimental Social Psychology, 25, 165.

Seefeldt, C. (2004). Social studies for the preschool/primary child (7th edition). New Jersey: Pearson Education. 
Serrat, O.(2009). Drawing Mind Maps, Asian Development Bank, 1-4

Snook, I. (2007). Values Educatıon in Context. D.N. Aspin and J.D. Chapman (eds.), Values Education and Lifelong Learning

Şeyihoğlu, A ve Kartal, A.(2010). Yapılandırıcı Yaklaşım Temelli İlköğretim Hayat Bilgisi ve Sosyal Bilgiler Derslerinde Zihin Haritalama Tekniğine İlişkin Öğretmen Görüşleri, Kuram ve Uygulamada Eğitim Bilimleri, 10, 3, 16131656

Yarar, S ve Tekbıyık, A. (2009). “Öğretmen Adaylarının Öğretmenlik Mesleğine Yönelik Sahip Oldukları Kişisel ve Mesleki Nitelikler Konusundaki Algılarının Incelenmesi", I. Uluslar Arası Eğitim Araştırmaları Konferansı, On Sekiz Mart Üniversitesi, Çanakkale.

Yıldırım. A ve Şimşek. H. (2006). Sosyal Bilimlerde Nitel Araştırma Yöntemleri. Ankara: Seçkin Yayınları

Zampetakis, L. A., Tsironis, L and Moustakis, V. (2007). Creativity development in engineering education: The case of mind mapping. Journal of Management Development, 26(4), 370-380. 


\section{SUMMARY}

The mind map was first developed by Tony Buzan as a short and attention grabbing note taking technique. Later on, the mind map technique, has been used not only as a note taking technique, but also it has been used in many different ways. The creation of a mind map begins with the expression of a main picture or an image, then related branches is drawn with the main theme, then the keywords is written in each branches, finally those branches are combined together with respect to the degree of relation of each keyword with the main idea. Mind maps are thought to be beneficiary in terms of its emotional expressivity because of their colorful, pictorial and easy-to-learn design. Hence, it is aimed to investigate its affective dimensions in this research because the affective characteristics of the learners can play a decisive role in the realization of an effective and permanent learning.

When the literature is examined, studies related with this topic were conducted and examined in terms of cognitive dimensions. However, mind maps also affect the affective side of human cognition. Especially mind maps can be useful in the value education. The student's associations and thought structure for a value are important in teaching values since the mind map is a collection of conceivable associations.

This research was conducted in order to reveal the views of primary school teachers, who have an important place in influencing future generations, over value education by investigating the mind maps that their opinions regarding this issue. This research is designed based on the qualitative research design in order to identify the opinions of primary school teachers about value education. For this purpose, phenomonologic approach was used in the research. Phenomenological research designs are more likely used to determine the investigate one's inner World and congitive structure in terms of a particular case, concept or event.

The study group of the study consists of 15 class volunteer primary school teachers randomly selected from their colegues in Isparta province. In the study, convenience sampling method was used to determine participants. The personal characteristics of participants are different from each other. Semi-structured interview form consisting of open-ended questions developed by the researcher was used as data collection tool. Opinions and evaluations of different faculty members from different universities working different areas in the field of educational sciences have been taken in order to test the validity of the questions in the semi-structured interview form.

The reliability of the data collection tool used in the research was determined by using the Miles and Huberman formula. Four expert opinions were consulted to ensure the reliability of the study. 95\% consensus (reliability) was provided in the reliability study conducted specifically for this study. Descriptive analysis was used to analyze the research data. The data in the descriptive analysis are summarized and interpreted according to the previously determined theme. The qualitative data are presented with given frequencies by converting them into numerical forms.

According to the findings, the most important values of teachers in value teaching were 'honesty' $(n=5)$, 'love' $(n=2)$ and 'respect' $(n=2)$ in their mind maps. In addition to these values, the universal values such as empathy, conscience, goodness, justice, trust, compassion were expressed by them. Altough the meanings of these values vary from individual to individual, but they are the significant, cohesive values in many societies. It is impossible to expect that every human being will have the same meaning for the same concept, because of their past experiences, and the existence of variables shaping people's feelings such as friends, identity, gender as well as culture. Thus, the values and meaning attributed by teacher also vary in this regard. This will be reflected by the values and teaching styles that teachers have.

When the participants were asked who is the most effective person shaping their values to which they mostly attach importance in their life, the answers are categorized as 'my family' $(n=3)$, 'my father' $(n=2)$ and 'our beloved prophet Muhammad (s.a.v) ' $(n=2)$. These answers confirm that people's sense of value is shaped from different sources. This research has shown that individuals are mostly affected by the family environment in which they are born and grown up. The development of attitudes and values first occurs in schools and in informal learning environments such as family and relatives outside the classroom. When teachers were asked about who should have the values they 
regard as important, the aswers are classifed as ' my wife/husband ' $(n=5)$ and 'my child' $(n=3)$. From here it is clear that a happy, peaceful and healthy society can be achieved through family. Indeed, the most important place where the value education also begins is the family. Later teachers take the responsibility of this in formal value education.

As a result, this study showed that the vast majority of the teachers who participated in the study were aware of the siginificance of value education. When their mental maps are taken into consideration, they give clues about the values they gave importance to and they wanted to teach. Teachers' attitudes and behaviors towards value education are significant for teaching those values more qualitatively. 


\section{GÖRÜŞME FORMU}

\section{Sayın Katılımcı,}

Size uygulanan bu görüşme formuyla değer öğretimine yönelik düşünceleriniz ortaya çıkarılacak ve düşüncelerinizi yansıtan zihin haritalarınız yorumlanacaktır. Bu amaçla aşağıdaki sorulara içtenlikle cevap vermeniz ve zihin haritasını çizerken yeterince anlaşılır olmasına dikkat etmeniz çalışmanın daha güvenilir olmasına katkı sağlayacaktır.

Soru 1:Sizin için bir insanda bulunması gereken en önemli değer nedir? Niçin? Ayrıca önemsediğiniz bu değerin sizde ne gibi çağrışımlar yaptığını lütfen aşağıya zihin haritası şeklinde örneğe bakarak çiziniz.

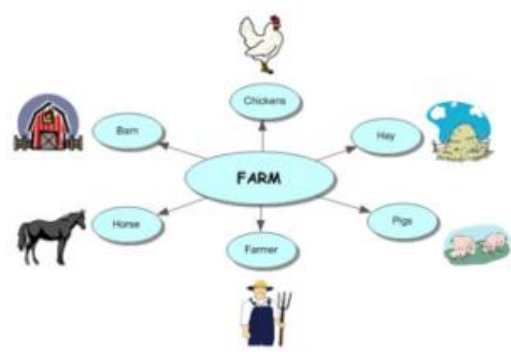

Soru 2: Siz sahip olduğunuzu düşündüğünüz en önemli değerde kimden etkilendiniz? Niçin?

Soru 3: Siz sahip olduğunuzu düşündüğünüz en önemli değerin en çok kimde olmasını isterdiniz? Niçin?

Soru 4: Siz sahip olduğunuzu düşündüğünüz bu değerin sizde olup olmadığını nasıl anlıyorsunuz? Niçin? 